\title{
Calibration of Ångström-Prescott Coefficients to Estimate Global Solar Radiation in Côte d'Ivoire
}

\author{
Maurice Aka Djoman \\ Wanignon Ferdinand Fassinou \\ Augustin Memeledje
}

Laboratoire des Sciences de la Matière, de l'Environnement et de l'Energie Solaire, UFR SSMT, Université Félix Houphouët-Boigny, Abidjan

Doi:10.19044/esj.2021.v17n37p24

Submitted: 22 January 2021

Accepted: 03 October 2021

Published: 31 October 2021
Copyright 2021 Author(s)

Under Creative Commons BY-NC-ND 4.0 OPEN ACCESS

Cite As:

Djoman M.A., Fassinou W.F. \& Memeledje A. (2021). Calibration of Ångström-Prescott Coefficients to Estimate Global Solar Radiation in Côte d'Ivoire. European Scientific Journal, ESJ, 17(37), 24.

https://doi.org/10.19044/esj.2021.v17n37p24

\section{Abstract}

In this study, we used monthly mean daily global radiation data and sunshine durations from nine (9) weather stations in Côte d'Ivoire to determine the annual Ångström-Prescott coefficients. The calibration of the Ångström-Prescott equation has been done through linear regression using the least square method. The empirical coefficients obtained are utilized to predict the global horizontal irradiance over the nine (9) weather stations of interest. Estimated and measured global radiations were compared using the root mean square error (RMSE), the mean bias error (MBE), the mean absolute bias error (MABE), the mean percentage error (MPE), the Nash-Sutcliffe coefficient of efficiency (NSE), and the statistic t-test (t-statistic). The low values of the statistic t-test (from 0.10 to 1.07 ) and MPE (from -0.413 to 0.201) indicate a good performance of the model. The high values of the coefficient of determination $\mathrm{R}^{2}$ (from 0.9776 to 0.9916 ) show a remarkable agreement between predicted and measured global solar radiations. This remark is also confirmed by the high values of NSE (from 0.8671 to 0.9819 ) closer to 1 . The obtained values of MBE (from -18.17 to $8.69 \mathrm{kWh} / \mathrm{m}^{2}$ ), MABE (from 7.16 to $8.52 \mathrm{kWh} / \mathrm{m}^{2}$ ), and RMSE (69.1 to $167.3 \mathrm{kWh} / \mathrm{m}^{2}$ ) show a low deviation or bias between the estimate and the measurements. The Ångström-Prescott coefficients determinants are consistent and can be used to efficiently calculate 
the global horizontal irradiance. The model established can be recommended to be used in the nine (9) weather stations to accurately estimate global solar radiation on horizontal surfaces.

Keywords: Ångström-Prescott Coefficients, Global Solar Radiation, Global Horizontal Irradiance, Statistic t-Test

\section{Introduction}

Information on solar radiation on the Earth's surface is required in many applications including agriculture, hydrology, meteorology, climatology, architecture, active and passive solar energy systems, and photovoltaic electricity production systems (Medeiros et al., 2017; Liu et al., 2009; Ishola, 2018; Girma, 2017; Jeong et al., 2018). The amount of global solar radiation received on a surface depends on numerous factors such as the altitude of the sun, the clearness index, the slope and the latitude of an area. Therefore, global solar radiation varies in space and time due to all these factors. A major challenge facing solar energy technologies is the availability of solar radiation data at the area of interest (Asilevi et al., 2019; Krivoshein et al., 2020). The optimization of the solar energy reception in different applications is highly dependent on the ability to measure and understand its spatial-temporal distribution (Ishola, 2018). Thus, adequate assessment of solar radiation data is crucial for planning and designing solar energy based systems (Mbiaké et al., 2018; Govindasamy \& Chetty, 2019; Ya’u et al., 2018; Al-Aboosi, 2020). For this reason, the best way to access solar radiation data at any location is to install suitable ground measuring instruments such as pyranometers and pyrheliometers and record its various components at a desired time scale (Al-Aboosi, 2020; Ener Kusen, 2018). In some regions around the world, measured solar radiation data do not exist or are available at a few places due to the cost, maintenance and instrument calibration requirement, while sunshine hours are measured at any locations (Ya'u et al., 2018; Al-Aboosi, 2020). Lack of adequate spatial and temporal resolution data on solar radiation is a worldwide problem especially in many developing countries. Developing methods to accurately estimate global solar radiation from other meteorological parameters is an alternative to overcome this problem. Numerous methods of varying complexity were established by scientists to estimate solar radiation including those based on generation from stochastic weather models (Richardson \& Wright, 1984), satellite image (Pinker et al., 1995), linear interpolation (Hay \& Suckling, 1979), artificial neural network (Tymvios et al., 2005), empirical relations using other meteorological variables (Angström, 1924; Prescott, 1940; Bristtow \& Campbell, 1984), and physical transfer processes (Gueymard, 2001). Among these estimation methods, there are robust numerical models requiring too 
many inputs parameters. These methods are only suitable for theoretical analysis rather than practical applications (Morcette et al., 2008; Manners et al., 2009). In contrast, simple empirical models remain the main tools for solar radiation estimation (Linacre, 1992) due to their simplicity, low computational costs, and easily accessible input data. These models were proposed worldwide to estimate solar radiation based on different available meteorological data. They are generally classified into four broad categories as follows (Besharat et al., 2013):

- Sunshine-based models (Angström, 1924; Prescott, 1940);

- Cloud cover-based models (Kasten, 1984);

- Temperature-based models (Bristow \& Campbell, 1984);

- Other meteorological parameters-based models (Swartman \& Ogunlade, 1967);

Therefore, the availability of meteorological parameters, which are used as the input of solar radiation models, is the important key to choose the proper radiation modes at any location (Ya'u et al., 2018).

The comparison of these different empirical models revealed that those based on sunshine duration give better results than the others in many studies (Trnka et al., 2005; Podesta et al., 2004; Zhou et al., 2005; Chen et al., 2004; Wu et al., 2007), in particular the Angström-Prescott equation (Ishola, 2018; Liu et al., 2015; Liu et al., 2012).

Ångström (1924) proposed a linear relationship between the ratio of global radiation to the corresponding value on a completely clear sky day and the ratio of daily sunshine hours to the maximum possible sunshine duration. To solve the difficulty introduced by the perfectly clear sky radiation data, Prescott (1940) replaced it by the extraterrestrial radiation and this modification led to the formulation of the Ångström-Prescott equation (1).

The Ångström-Prescott regression coefficients a and b result essentially from the empirical attenuation coefficients of extraterrestrial radiation that reaches Earth's surface through the atmosphere. The global heterogeneity of atmospheric thickness and its components distribution objectively produce regional differences in the magnitude of global solar radiation reaching the surface (Xia et al., 2019). The coefficients a and b of Ångström-Prescott equation are site-specific. They depend on physical characteristics of the atmospheric layer and are influenced by local latitude and altitude without missing the seasonal variability of weather conditions (rainfall, wind, humidity and aerosol thickness and concentrations). The empirical coefficients $a$ and $b$ should be calibrated for a certain region and cannot be used directly for other regions (Ekici, 2019). Since the establishment of the Ångström-Prescott equation, it has undergone many modifications focused on improving its prediction accuracy and its general validity as summarized by Liu et al. (2009). The improvements consisted in relating the 
parameters to geographical factors (Glover \& McCulloch, 1958) or to meteorological variables to introduce additional variables into the equation (Ododo et al., 1995; Garg \& Garg, 1983) or simply to increase the polynomial order of relative sunshine duration. Although some authors claimed that these modified models were better than the conventional Ångström-Prescott model, this is apparently not the case in many comparative studies undertaken by other researchers (Iziomon \& Mayer, 2002; Boisvert et al., 1990; Soler, 1990; Ulgen \& Hepbasli, 2004; Ertekin \& Yaldiz, 2000; Yorukoglu \& Celik, 2006; Zho et al., 2005). Since these modifications did not bring any gain in the estimation accuracy, it is questionable whether it is worthy to adopt such complexity at the risk of losing the simplicity and convenience of the original Ångström-Prescott model. In fact, the other meteorological factors were already implicitly incorporated into the information of the Ångström-Prescott coefficients. This is easily explained by the fact that sunshine duration is linked to the variability of the other meteorological parameters. Therefore, the local calibration of the Ångström-Prescott equation is more important than developing new methods or their modification (Liu et al., 2009).

In Côte d'Ivoire, no study on the modeling of Ångström-Prescott equation was undertaken. This study aims to determine the Ångström-Prescott coefficients in nine (9) meteorological stations from global solar radiation data on a horizontal surface and sunshine hours, and the obtained results was used to estimate global horizontal irradiance.

\section{Methods and Materials}

\subsection{Theoretical Aspect}

The global solar radiation reaching the earth's surface is the result of complex interactions between solar rays from the top of the earth's atmosphere and the climatic conditions at the site of interest. The Ångström-Prescott equation establishes a functional relationship between clearness index and relative sunshine duration as follow:

$$
\frac{\mathrm{H}}{\mathrm{H}_{0}}=\mathrm{a}+\mathrm{b} \frac{\mathrm{S}}{\mathrm{S}_{0}}
$$

where $\mathrm{H}$ and $\mathrm{H}_{0}$ are, respectively, global and extraterrestrial radiations, $\mathrm{S}$ the actual daily sunshine duration and $\mathrm{S}_{0}$ the theoretical sunshine duration or day length.

To determine $\mathrm{H}_{0}$ and $\mathrm{S}_{0}$, it is necessary to go through theoretical calculations. So the daily mean extraterrestrial radiation on a horizontal surface $\mathrm{H}_{0}$ can be calculated for a typical day of a month according to the following equation: 


$$
\mathrm{H}_{0}=\frac{24}{\pi} \mathrm{I}_{\mathrm{sc}} \mathrm{E}_{0}\left(\frac{\pi}{180} \omega_{\mathrm{s}} \sin \delta \sin \varphi+\cos \delta \cos \varphi \sin \omega_{\mathrm{s}}\right)
$$

where $I_{s c}=(1367 \pm 4) W \cdot m^{-2}$ is the solar constant, $E_{0}$ the eccentricity correction factor of the Earth's orbit, $\omega_{\mathrm{s}}$ the sunset hour angle, $\delta$ the solar declination and $\varphi$ the latitude of the location.

The eccentricity correction factor is determined by the modified Duffie and Beckman's equation :

$$
E_{0}=1+0.034 \cos \left\lfloor\frac{2 \pi(n-2)}{365}\right]
$$

where $\mathrm{n}$ is the number of day of the year, starting from the first of January ( $n=1)$ and ended on December $31^{\text {th }}(n=365$ or 366 depending on the year).

The solar declination can be calculated from the equation:

$$
\delta=23.429 \sin \left(\frac{2 \pi n}{370.84}-1.3616\right)+0.242 \sin \left(\frac{4 \pi n}{360.15}-1.93\right)
$$

The sunset hour angle on a horizontal surface can be obtained by the relationship:

$$
\omega_{\mathrm{s}}=\cos ^{-1}(-\tan \varphi \tan \delta)
$$

This expression leads to determine the maximum sunshine duration of a day on a horizontal surface in hours as follows:

$$
\mathrm{S}_{0}=2 \omega_{\mathrm{s}}=\frac{2}{15} \cos ^{-1}(-\tan \varphi \tan \delta)
$$

\subsection{Solar Radiation Data}

To carry out the study, we used data from nine (9) radiometric stations in Côte d'Ivoire from 2006 to 2010. Figure 1 shows the geographical locations of the selected weather stations. The data including the sunshine duration and monthly mean daily solar radiation on horizontal surfaces are collected by Société d'Exploitation et de Développement Aéroportuaire, Aéronautique et Météorologique(SODEXAM), the company in charge of the meteorological parameters measurement in Côte d'Ivoire. 


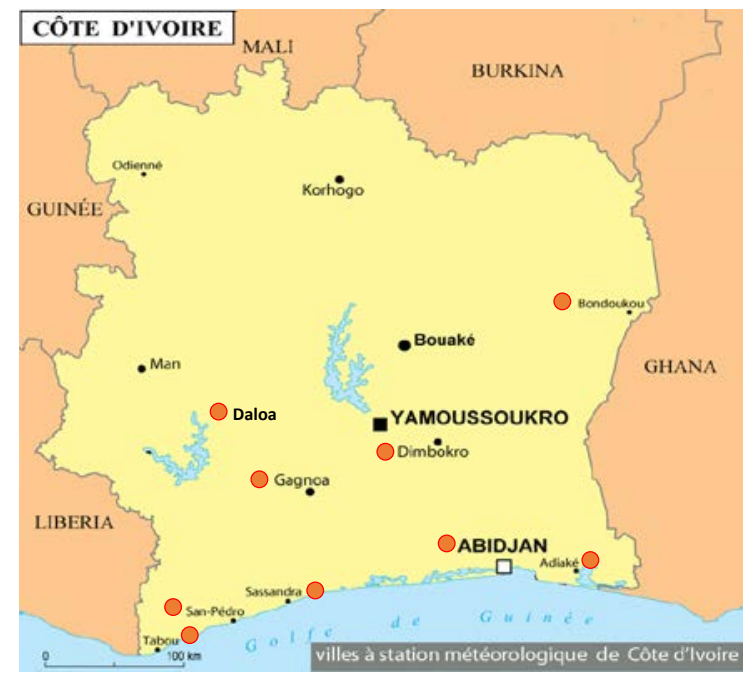

Figure 1. Geographical Positions of the Selected Weather Stations (SODEXAM)

Table 1 shows the geographical coordinates of each site as well as the measurements periods.

Côte d'Ivoire is a West Africa country located between latitudes $4{ }^{\circ} \mathrm{N}$ and $10^{\circ} \mathrm{N}$. It is between two main climatic zones, i.e., the humid tropical climate in the south and the Sudanese climate in the north. The coefficients of Ångström-Prescott equation $\mathrm{a}$ and $\mathrm{b}$ were determined through linear regression analysis by using the ordinary least squares method relating monthly mean daily clearness index to the corresponding relative sunshine duration at each station.

Table 1. Geographical Coordinates of the Sites and the Periods of the Measurements

\begin{tabular}{|l|l|l|l|l|}
\hline Station & Latitude $\mathbf{(}^{\circ}$ ) & Longitude $\mathbf{(}^{\circ}$ ) & Elevation (m) & Period \\
\hline Abidjan & 5.260291 & -3.927276 & 8 & $2006-2010$ \\
\hline Adiaké & 5.286841 & -3.302014 & 39 & $2006-2010$ \\
\hline Bondoukou & 8.016067 & -2.762753 & 370 & $2006-2010$ \\
\hline Daloa & 6.87669 & -6.45161 & 277 & $2006-2010$ \\
\hline Dimbokro & 6.649426 & -4.704057 & 92 & $2006-2010$ \\
\hline Gagnoa & 6.132974 & -5.95177 & 210 & $2006-2010$ \\
\hline San-Pédro & 4.746199 & -6.660735 & 30 & $2006-2010$ \\
\hline Sassandra & 4.951934 & -6.088562 & 66 & $2006-2010$ \\
\hline Tabou & 4.41397 & -7.363371 & 21 & $2006-2010$ \\
\hline
\end{tabular}

The values $a$ and $b$ were obtained from 10-days data covering the period 2006 to 2010, collected annually in each weather station.

\subsection{Analysis Methods}

After calibrating the Ångström-Prescott equation, the model is evaluated by comparing the measured and estimated values of the monthly 
mean daily irradiation $\mathrm{H}$. The performance of the model is determined by calculating the root mean square error (RMSE), the mean bias error (MBE), the mean absolute bias error (MABE), the mean percentage error (MPE), the $\mathrm{t}$-statistic ( $\mathrm{t}$-stat), and the Nash-Sutcliffe coefficient of efficiency (NSE) which are defined as follows:

$$
\begin{aligned}
& \text { RMSE }=\sqrt{\frac{1}{n} \sum_{i=1}^{n}\left(c_{i}-m_{i}\right)^{2}} \\
& \text { MBE }=\frac{1}{n} \sum_{i=1}^{n}\left(c_{i}-m_{i}\right) \\
& \text { MABE }=\frac{1}{n} \sum_{i=1}^{n}\left|c_{i}-m_{i}\right| \\
& \text { MPE }=\frac{1}{n} \sum_{i=1}^{n} \frac{\left(c_{i}-m_{i}\right)}{m_{i}} \times 100 \\
& \text { t-stat }=\sqrt{\frac{(n-1) M B E^{2}}{R M S E^{2}-M B E^{2}}} \\
& \text { NSE }=1-\frac{\sum_{i=1}^{n}\left(m_{i}-c_{i}\right)^{2}}{\sum_{i=1}^{n}\left(m_{i}-m_{a}\right)^{2}}
\end{aligned}
$$

Where, $n$ is the number of data pairs, ${ }_{i}$ the predicted values of $H, m_{i}$ the measured values of $\mathrm{H}$ and $\mathrm{m}_{\mathrm{a}}$ the average of measured values of $\mathrm{H}$.

The RMSE and MBE are the most commonly used indicators to compare models for solar radiation estimations. The RMSE provides information on the short term performance of correlations by allowing a term by term comparison of the actual deviation between the estimated and measured values. Meanwhile, the MBE shows the overestimation or underestimation of the computed values. Low values of RMSE and MBE are expected but depending on the data, some fluctuations can be observed. Togrull et al. (2000) demonstrated that the use of RMSE and MBE in isolation is not an adequate method for evaluating the model performance. Thus, it was concluded that the addition of the statistic t-test $\mathrm{t}$-stat gave more reliable and explanatory results for the evaluation and comparison of solar radiation models (Almorox et al., 2005). In the same way, Jacovides (Jacovides \& Kontoyiannis, 1995; Jacivides, 2000) demonstrated that the separated use of RMSE and MBE indicators can lead to the incorrect selection of the best model. It was commonly recommended to use the statistic t-test t-stat in conjunction with RMSE and MBE in order to reliably assess a model's performance (Almorox et al., 2005). 
The MABE measures the average of the absolute differences between predicted and measured values. Low values of MABE are desired.

The statistic t-test t-stat is given as a function of the widely used root mean square error and mean bias error. In this paper, we used the $t$-stat in conjunction with the RMSE and MBE for the evaluation of the model. We assume that the smaller the value of $\mathrm{t}$-stat, the better the model's performance. To determine whether a model is statistically significant, the absolute value of the calculated t-stat must be less than the critical t-stat value obtained from the statistical tables. By referring to the number of data used in this work ( $n=60)$ and for a confidence level of 95\%, the critical value of statistic t-test is $t_{\text {crit }}=1.671$ for a one-sided test.

MPE is defined as the percentage deviation of the estimated values from the measured ones. For a better model performance, a low value of MPE is desirable and the percentage error between $-10 \%$ and $+10 \%$ is considered acceptable (Samanta et al., 2020).

NSE is a simple measure to determine the model precision by plotting observed values against predicted values in a 1:1 line. Generally, NSE ranges from $-\infty$ to 1.0 and the model is more efficient when NSE is closer to 1 (Samanta et al., 2020). So, in regression procedures, NSE is equivalent to the coefficient of determination $\left(R^{2}\right)$.

\section{Results and Discussion}

The results of the regression analysis for the five (5) years (2006-2010) of monthly mean daily irradiations for each weather station can be seen in Table 2. The different statistical error indicators and tests are also given in Table 4. According to Table 2, coefficient a vary from 0.2154 in Gagnoa to 0.2652 in Bondoukou, b vary from 0.3808 in Dimbokro to 0.4182 in Abidjan. Parameter b is slightly stable with a coefficient of variation (CV) of $3.36 \%$ against $9.85 \%$ for a. Obviously, the Ångström-Prescott coefficients vary from one site to another. These variations in $a$ and $b$ values can be explained as a consequence of local atmospheric climatology. This demonstrates the importance of local calibration of the Ångström-Prescott equation. On the contrary, the sum $(a+b)$ is stable with a CV of $1.5 \%$ in the study area, indicating that the overall atmospheric transmission under clear sky conditions is the same in each station.

The calibrated coefficients have a physical meaning because their sum always remains less than one throughout the study area. In the literature (Mbiaké et al., 2018; Besharat et al., 2013; Martinez-Lozano et al., 1984; Nwokolo \& Ogbulezie, 2018), the different Ångström-Prescott coefficients determined in several countries on the five continents ( 308 values) show that a varies between -0.1910 and 0.713 , while $b$ varies between 0.1900 and 
0.7874. By comparison, the values of $a$ and $b$ obtained belong to these respective intervals.

Table 2. Regression Results for Each Site

\begin{tabular}{|c|c|c|c|c|}
\hline Cities & $\mathrm{a}$ & $\mathbf{b}$ & $\mathrm{a}+\mathrm{b}$ & $\mathrm{R}^{2}$ \\
\hline Abidjan & 0.2168 & 0.4179 & 0.6347 & 0.9838 \\
\hline Adiaké & 0.2210 & 0.4066 & 0.6276 & 0.9801 \\
\hline Bondoukou & 0.2652 & 0.3907 & 0.6559 & 0.9843 \\
\hline Daloa & 0.2156 & 0.4182 & 0.6338 & 0.9828 \\
\hline Dimbokro & 0.2707 & 0.3808 & 0.6515 & 0.9886 \\
\hline Gagnoa & 0.2154 & 0.4173 & 0.6327 & 0.9776 \\
\hline San-Pédro & 0.2176 & 0.4159 & 0.6335 & 0.9834 \\
\hline Sassandra & 0.2169 & 0.4172 & 0.6341 & 0.9780 \\
\hline Tabou & 0.2165 & 0.4144 & 0.6309 & 0.9916 \\
\hline
\end{tabular}

Table 3 gives a comparative view of the Ångström-Prescott coefficients determined in some places in Africa. From this table, it is seen that the values obtained in this work are of the same order of magnitude as those of the other regions of Africa, especially for Bobo Dioulasso $(a=0.21$ and $b=0.46)$, Douala $(a=0.2530$ and $b=0.4266)$, Ibadan $(a=0.308$ and $b=0.358)$, Kumasi $(a=0.22$ and $b=0.43)$, and Lome $(a=0.263$ and $b=0.374$ ) which are five regions in West Africa like Côte d'Ivoire.

Table 3. Values of Ångström-Prescott Coefficients in other African Countries

\begin{tabular}{|c|c|c|c|c|c|c|}
\hline $\mathbf{a}$ & $\mathbf{b}$ & $\mathbf{a}+\mathbf{b}$ & Authors & Year & Region & Country \\
\hline 0.22 & 0.43 & 0.65 & Quansah and Neba & 2014 & Kumasi & Ghana \\
\hline 0.250 & 0.470 & 0.720 & Abbas et Elnesr & 1977 & Giza & Egypt \\
\hline 0.367 & 0.367 & 0.734 & Chegaar et Chibani & 2001 & Beni Abbas & Algeria \\
\hline 0.308 & 0.358 & 0.666 & Fagbeule & 1993 & Ibadan & Nigeria \\
\hline 0.430 & 0.320 & 0.750 & Davies & 1965 & Ford Lamy & Chad \\
\hline 0.230 & 0.620 & 0.850 & Glover et McCulloch & 1958 & Kabete & Kenya \\
\hline 0.240 & 0.513 & 0.753 & Jain et Jain & 1988 & 8 stations & Zambia \\
\hline 0.320 & 0.400 & 0.720 & Khogali & 1983 & Port Sudan & Sudan \\
\hline 0.320 & 0.460 & 0.780 & Lewis & 1983 & Harare & Zimbabwe \\
\hline 0.210 & 0.562 & 0.772 & Mabasa et al. & 2020 & Mthatha & South Africa \\
\hline 0.210 & 0.520 & 0.730 & Page & 1961 & Kinshasa & Zaire \\
\hline 0.300 & 0.480 & 0.780 & Page & 1961 & Antananarivo & Madagascar \\
\hline 0.240 & 0.470 & 0.710 & Rijks et Huxley & 1964 & Kampala & Uganda \\
\hline 0.263 & 0.374 & 0.637 & Banna and Gnininri & 1998 & Lome & Togo \\
\hline 0.2530 & 0.4266 & 0.6796 & Afungchui and Neba & 2013 & Douala & Cameroon \\
\hline 0.21 & 0.46 & 0.67 & $\begin{array}{c}\text { Coulibaly and } \\
\text { Ouedoraogo }\end{array}$ & 2016 & Bobo & Burkina Faso \\
\hline
\end{tabular}

By observing Table 4, the NSE values that range from 0.8671 to 0.9819 are closer to 1 in all sites. This shows that the model have a good performance. This remark is also confirmed by the low values of $t$ - stat (varying from 0.10 
to 1.07) which are all less than 1.671. Moreover, MBE values (range from 18.17 to $8.69 \mathrm{kWh} / \mathrm{m}^{2} /$ day) point out that the model slightly underestimates the solar radiation values in all sites except in Abidjan where the model overestimates them. The MABE values (ranging from 7.16 to 8.52 $\mathrm{kWh} / \mathrm{m}^{2} /$ day) reveal that the absolute bias between calculated and measured values is low. It is the same for the RMSE values (from 69 to $167 \mathrm{kWh} / \mathrm{m}^{2} /$ day ) which display that the absolute mean deviation between estimated and measured values is also low. In sum, all the results of the statistical indicators and tests support that the estimated values of the global solar radiation are close to the measured ones. The Angström-Prescott coefficients obtained by the modeling are consistent. They can allow making a good estimate of the global horizontal irradiance in the nine (9) meteorological stations.

Table 4. Statistical Error Indicators of the Model

\begin{tabular}{|c|c|c|c|c|c|c|}
\hline Cities & $\begin{array}{c}\text { MBE } \\
\left(\mathrm{kWh} / \mathrm{m}^{2} / \mathrm{day}\right)\end{array}$ & $\begin{array}{c}\text { MABE } \\
\left(\mathrm{kWh} / \mathrm{m}^{2} / \mathrm{day}\right)\end{array}$ & $\begin{array}{c}\mathrm{RMSE} \\
\left(\mathrm{kWh} / \mathrm{m}^{2} / \mathrm{day}\right)\end{array}$ & MPE$(\%)$ & NSE & t-stat \\
\hline Abidjan & 8.69 & 6.87 & 69.1 & 0.201 & 0.9819 & 1.07 \\
\hline Adiaké & -1.14 & 7.84 & 84.3 & -0.413 & 0.9774 & 0.10 \\
\hline Bondoukou & -15.26 & 8.52 & 148.6 & -0.320 & 0.8961 & 0.79 \\
\hline Daloa & -8.54 & 7.57 & 100.9 & -0.205 & 0.9522 & 0.65 \\
\hline Dimbokro & -13.75 & 7.23 & 122.7 & -0.291 & 0.9185 & 0.87 \\
\hline Gagnoa & -12.20 & 8.01 & 124.1 & -0.278 & 0.9129 & 0.76 \\
\hline San-Pédro & -17.04 & 8.08 & 156.6 & -0.345 & 0.8994 & 0.84 \\
\hline Sassandra & -18.17 & 8.47 & 167.3 & -0.364 & 0.8671 & 0.84 \\
\hline Tabou & -8.71 & 7.16 & 91.5 & -0.204 & 0.9737 & 0.73 \\
\hline
\end{tabular}

\section{Conclusion}

- $\quad$ Angström-Prescott equation is calibrated, for the first time, in Côte d'Ivoire using nine (9) weather stations data, which is sampled in 10-days global radiation and sunshine hours.

- $\quad$ The performance of the resulting annual model was evaluated using some statistical error methods. The results obtained show a strong correlation with a high determination coefficient for each weather station confirmed by NSE closer to 1 . The model performed very well due to the low values of t-stat. The RMSE and MBE related to the comparison between measured and estimated monthly mean daily global radiation ranged, respectively, from 69.1 to 167.3 and from -8.71 to $8.69 \mathrm{kWh} \cdot \mathrm{m}^{-2}$.day ${ }^{-1}$. Those values are in convenient with those encountered in literature.

- The comparisons made with other values of the AngstromPrescott coefficients throughout the world and specifically in certain 
regions of Africa confirm that the coefficients obtained have a good consistency.

- $\quad$ Our results reveal that the model proposed in this work may be used satisfactory for the estimation of monthly mean daily global solar radiation in the nine (9) weather stations in Côte d'Ivoire.

\section{Nomenclature}

a: Ångström-Prescott regression coefficient

b: Ångström-Prescott regression coefficient

$\mathrm{c}_{\mathrm{i}}$ : Predicted values of $\mathrm{H}$

CV: Coefficient of variation

$\mathrm{E}_{0}$ : Eccentricity correction function of the Earth's orbit

$\mathrm{H}$ : Global horizontal radiation $\left(\mathrm{kWh} / \mathrm{m}^{2}\right)$

$\mathrm{H}_{0}$ : Extraterrestrial radiation $\left(\mathrm{kWh} / \mathrm{m}^{2}\right)$

$\mathrm{I}_{\mathrm{sc}}$ : Solar constant $\left(\mathrm{W} / \mathrm{m}^{2}\right)$

$\mathrm{m}_{\mathrm{a}}$ : Average of measured values of $\mathrm{H}\left(\mathrm{kWh} / \mathrm{m}^{2}\right)$

$\mathrm{m}_{\mathrm{i}}$ : Measured values of $\mathrm{H}\left(\mathrm{kWh} / \mathrm{m}^{2}\right)$

$\mathrm{S}$ : Sunshine duration (h)

$\mathrm{S}_{0}$ : Maximum sunshine duration (h)

$\delta$ : Solar declination $\left(^{\circ}\right)$

$\varphi$ : Latitude $\left(^{\circ}\right)$

$\omega_{\mathrm{s}}$ : Sunset hour angle $\left(^{\circ}\right)$

\section{References:}

1. Almorox, J., Benito, M. \& Hontoria, C. (2005). Estimation of monthly Angström-Prescott equation coefficients from measured daily data in Toledo, Spain. Renewable Energy 30 931-936.

2. Al-Aboosi, F. Y. (2020). Models and hierarchical methodologies for evaluating solar energy availability under different sky conditions toward enhancing concentrating solar collectors use: Texas as a case study. International Journal of Energy and Environmental Engineering 11:177-205. https://doi.org/10.1007/s40095-019-00326-z.

3. Angström, A. (1924). Solar and terrestrial radiation. Quart. J. Roy. Met. Soc., 50, 121-125.

4. Asilevi, P. J., Quansah, E., Amekudzi, L. K., Annor, T. \& Klutse N. A. B. (2019). Modeling the spatial distribution of Global Solar Radiation (GSR) over Ghana using Ångström-Prescott sunshine duration model. Scientific African 4e00094 
5. Besharat, F., Dehghan, A. A. \& Faghih, A. R. (2013). Empirical models for estimating global solar radiation: A review and case study. Renewable and Sustainable Energy Reviews 21 798-821.

6. Boisvert, J. B. Hayhoe, H. N. \& Dubé, P. A. (1990). Improving the estimation of global solar radiation across Canada. Agric. For. Meteorol. 52 (3-4), 275-286.

7. Bristtow, K. L. \& Campbell, G. S. (1984). On the relationship between incoming solar radiation and daily maximum and minimum temperature. Agric. For. Meteorol. 31, 159-166.

8. Chen, R., Kang, E., Yang, J., Lu, S. \& Zhao, W. (2004). Validation of five global radiation models with measured daily data in China. Energy Convers. Manage., 45 (s11-12): 1759-1769.

9. Ekici, C. (2019). Total Global Solar Radiation Estimation Models and Applications: A Review. International Journal of Innovative Technology and Interdisciplinary Sciences. Vol.2, Is.3, pp.236-252, DOI: https://doi.org/10.15157/IJITIS.2019.2.3.236-252

10. Ener Kusen, S. (2018). Performance evaluation of a couple method for the estimation of daily global solar radiation on a horizontal surface. Atmosfera 31(4), 347-354 doi: 10.20937/ATM.2018.31.04.03

11. Ertekin, C. \& Yaldiz, O. (2000). Comparison of some existing models for estimating global solar radiation for Antalya (Turkey). Energ. Convers. Manage. 41, 311-330.

12. Garg, H. P. \& Garg, S. T. (1983). Prediction of global solar radiation from bright sunshine hours and other meteorological data. Energy Conversion and Management 23 (2), 113-118.

13. Girma, D. N. (2017). Estimation of monthly average daily solar radiation from meteorological parameters: sunshine hours and measured temperature in Tepi, Ethiopia. International Journal of Energy and Environment Science. Vol. 3, No. 1, , pp. 19-26.

14. Glover, J. \& McCulloch, J. S. G. (1958). The empirical relation between solar radiation and hours of sunshine. Quart. J. Roy. Met. Soc., 84 (360), 172-175.

15. Govindasamy, T. R. \& Chetty, N. (2019). Non-linear multivariate models for estimating global solar radiation received across five cities in South Africa. Journal of Energy in Southern Africa 30(2): 38-51.

16. Gueymard, C. (2001). Parameterized transmittance model for direct beam and circumsolar spectral irradiance. Solar Energy, Vol. 71, Is. 5 325-346.

17. Hay, J. E. \& Suckling, P. W. (1979). An assessment of the net-works for measuring and modeling solar radiation in British Columbia and adjacent areas of western Canada. The Canadian Geographer, Vol. 23, Is. 3, 222-238. 
18. Ishola, K. A. (2018). Developing regional calibration coefficients for estimation of hourly global solar radiation in Ireland. International Journal of Sustainable Energy. https://doi.org/10.1080/147864511499645.

19. Iziomon, M. G. \& Mayer, H. (2002). Assessment of some global solar radiation parameterizations. J. Atmos. Solar-Terr. Phy. 64: 1631-43.

20. Jacivides, C. P. (2000). Reply to comment on 'Statistical procedures for the evaluation of evaporation computing models'. Agric Water Manage 41 311-330.

21. Jacovides, C. P. \& Kontoyiannis, H. (1995). Statistical procedures for the evaluation of evaporation computing models. Agric Water Manage 27 365-371

22. Jeong, H., Bhattari, R., Hwang, S., Son, J. G. \& Jang, T. (2018). How Ångström-Prescott Coefficients Alter the Estimation of Agricultural Water Demand in South Korea. Water, 10, 1851; doi:10.3390/w10121851

23. Kasten, F. (1984). Parametriesierung der Globalstrahlung durch Bedekungsgrad undTrübungsfaktor. Annalen der Meteorologie Neue Folge, 20, 49-50.

24. Krivoshein, Y. O., Tolstykh, A. V., Tsvetkov, N. A. \& Khutornoy, A. N. (2020). Mathematical model for calculating solar radiation on horizontal and inclined surfaces for the conditions of Yakutsk. IOP Conf. Series: Earth and Environmental Science 408012002. doi:10.1088/1755-1315/408/1/012002

25. Linacre, E. (1992). Climate data and resources, a reference and guide. NY: Routledge, p. 366.

26. Liu et al., J. (2015). Changes in the relationship between solar radiation and sunshine duration in large cities of China. Energy 82 589600.

27. Liu et al., X. (2009). Calibration of the Angström-Prescott coefficients (a, b) under different time scales and their impacts in estimating global solar radiation in the Yellow River basin. Agricultural and Forest Meteorology 149 697-710.

28. Liu et al., X. (2012). Assessing models for parameters of the Angström-Prescott formula in China. Applied Energy 96 327-338.

29. Manners, J., Thelen, C., Petch, J., Hill, P. \& Edwards, J. M. (2009). Two fast radiative transfert methods to improve the temporal sampling of clouds in numerical weather prediction and climate models. Quart. J. Roy. Met. Soc., 135: 457-68.

30. Martinez-Lozano, J.A., Tena, F., Onrubia, J. E. \& De La Rubia, J. (1984). The historical evolution of the Ångström formula and its 
modifications: Review and bibliography. Agricultural and forest Meteorology, 33 109-128.

31. Mbiaké, R., Wakata, B. A., Mfoumou, E. \& Ndjeuna et al., E. (2018). The relationship between global solar radiation and sunshine durations in Cameroon. Open Journal of Air Pollution, 7, 107-119.

32. Medeiros et al., F. J. (2017). Calibration of Angström-Prescott equation to estimate daily solar radiation on Rio Grande do Norte state, Brazil. Revista Brasileira de Meteorologia, v. 32, n. 3, 409-461,

33. Morcette, J. J., Mozdzynski, G. \& Leutbecher, M. (2008). A reduced radiation grid for the ECMWF integrated forcasting system. Mon. Wea. Rev. 136, 4760-72.

34. Nwokolo, S.C. \& Ogbulezie, J.C. (2018). A quantitative review and classification of empirical models for predicting global solar radiation in West Africa. Beni-Suef Univ. J. Basic Appl. Sci. 7 367-396

35. Ododo, J. C., Sulaiman, A. T., Aidan, J., Yguda, M. M. \& Ogbu, F. A. (1995). The importance of maximum air temperature in parameterization of solar radiation in Nigeria. Renewable Energy 6 (7), 751-763.

36. Pinker, R. T., Frouin, R. \& Li, Z. (1995). A review of satellite methods to derive surface shortwave irradiance, Remote Sensing of Environment, Vol. 51, Is. 1, 108-124.

37. Podesta, G. P., Núñez, L., Villanueva, C. A. \& Skansi, M. A. (2004), Estimating daily solar radiation in the Arentine Pampas. Agric. For. Meteorol. 123: 41-53.

38. Prescott, J. A. (1940). Evaporation from a water surface in relation to solar radiation. Trans. Roy. Soc. Sci., Australia 64, 114-125.

39. Richardson, C. W. \& Wright, D. A. (1984). WGN: a model for generating daily weather variables. US Department of Agriculture, Agricultural Research Service, ARS-8.

40. Samanta, S., Banerjee, S., Mukherje, A., Patra, P. K. \& Chakraborty, P. K. (2020). Determining the radiation use efficiency of potato using sunshine hour data: a simple and costless approach. Spanish Journal of Agricultural Research 18(2) e0801, 15 pages https://doi.org/10.5424/sjar/2020182-15561.

41. Soler, A. (1990). Statistical comparison for 77 European stations of 7 sunshine-based models. Solar Energy 45 (6), 365-370.

42. Swartman, R. K. \& Ogunlade, O. (1967). Solar radiation estimates from common parameters. Solar Energy; 11: 170-2

43. Togrull, I. T., Togrul, H. \& Evin, D. (2000). Estimation of global solar radiation under clear sky condition in Turkey. Renewable Energy 21 271-287 
44. Trnka, M., Zaluk, Z., Eitzinger, J. \& Dubrovsky, M. (2005). Global solar radiation in central European lowlands estimated by various empirical formulae. Agric. For. Meteorol. 131: 54-76.

45. Tymvios, F. S., Jacovides, C. P., Michaelides, S. C. \& Scouteli, C. (2005). Comparative study of Ångström's and artificial neural networks' methodologies in estimating global solar radiation. Solar Energy, Vol. 78, Is. 6 752-762.

46. Ulgen, K. \& Hepbasli, A. (2004). Solar radiation models. Part 2: Comparison and developing new models. Energy Sources 26 (5), 752762.

47. Wu, G. F., Liu, Y. L. \& Wang, T. J. (2007). Methods and strategy for modeling daily global radiation with measured meteorological data a case study in Nanchang station, china. Energy Conversion and Management 48 2447-2452.

48. Xia, X., Zhu, X., Pan, Y., Zhao, X. \& Zhang, J. (2019). Calibration and Optimization of the Ångström-Prescott coefficients for calculating $\mathrm{ET}_{0}$ within a Year in China: The Best Corrected Data Time Scale and Optimization Parameters. Water, 11, 1706; doi:10.3390/w11081706

49. Ya'u, M. J., Gele, M. A., Ali, Y. Y. \& Alhaj, A. M. (2018). Global Solar Radiation Models : A Review. Journal of Photonic Materials and Technology. Vol.4, No.1, 2018, pp.26-32. doi: 10.11648/j.jmpt. 0401.15.

50. Yorukoglu, M. \& Celik, A. N. (2006). A critical review on the estimation of daily global solar radiation from sunshine duration. Energ. Convers. Manage. 47 (15-16), 2441-2450.

51. Zhou, J., Wu, Y. \& Yan, G. (2005). General formula for estimation of monthly average daily global solar radiation in China. Energy Convers. Manage., 46 (2): 257-268. 